\title{
DE
}

OPEN

\section{Human trafficking: Commercial sexual exploitation and forced domestic labour in African literature}

\author{
Evelyn Nwachukwu Urama \& Chukwuka Ogbu Nwachukwu \\ Federal University Ndufu-Alike Ikwo, Ebonyi State, Nigeria \\ evelynurama@gmail.com
}

\begin{abstract}
Just like social occurrences such as human sacrifice and slavery enhanced retardation of progress in Africa in the past, trafficking is another social occurrence addressed in contemporary African literature that impedes progress and tarnishes the image of the victims. Human trafficking is rampant in Africans and some part of the world in this $21^{\text {st }}$ century. This paper examines how Akachi Adimora-Ezeigbo's Trafficked (2008) and Chika Unigwe's On Black Sisters' Street (2009) highlight social occurrences and how they contribute to the spread of girl trafficking in Africa. It also explores how both men and women are partners in trafficking, forming trafficking networks that lure girls from Nigeria to Europe and make huge profits from their misery. These pimps use 'juju magic' and rituals as a threat to exert complete control over the girls and also to ensure their compliance. The trafficked girls share their life experiences by telling their tales of woes exposing the shame that accompanies the sex trade and the stigmatization they suffer in the society. Their experiences are presented by the authors to highlight the trafficked girls' pains, misery and struggle for freedom in order to appeal to everybody in the society to fight against human trafficking. The paper also examines how these exploited and depressed trafficked girls that have lost their self-esteem can still live fulfilled lives if government agencies and nongovernmental organizations come to their rescue.
\end{abstract}

Key words: trafficking, social occurrences, sexual and domestic slavery and commercial sex exploitation

\section{Introduction}

Human trafficking is a kind of modern slavery and the victims are mainly women and girls. Akachi Adimora-Ezeigbo's novel, Trafficked (2008) portrays how materialism has led traffickers into criminal acts that impede the progress of other individuals. Chika Unigwe's On Black Sisters' Street (2009) portrays not only the traffickers' quest for wealth but also how poverty, peer pressure, laziness, lack of parental care, war and cultural practices like devaluation of women and girls in some African societies make women vulnerable to trafficking. United Nations 
Office on Drugs and Crime (UNODC) on 'Human Trafficking and Migrant Smuggling' (2011) defines human trafficking as the acquisition of people by improper means such as force, fraud or deception, with the aim of exploiting them. Human trafficking is therefore a serious crime and a violation of human rights that enhances retardation of progress in some country of the world today. Thousands of men, women and children fall into the hands of traffickers both locally and internationally every year. They are lured into trafficking with promises of greener pastures and good living by the traffickers. UNODC Article 3, paragraph (a) of 'The Protocol to Prevent, Suppress and Punish Trafficking in Persons' (2012) further stresses that trafficked persons are exploited by subjecting them to prostitution and other forms of sexual exploitation, forced labour or services, slavery or practices similar to slavery, servitude or the removal of organs.

Literature is a representation of life and the mirror of the society; the representation of the traffickers' actions in literature is therefore to evoke and reinvigorate its confrontation from people all over the world. The trafficked girls represented in Unigwe's On Black Sisters' Street (2008) are deprived, violated and sexually abused in Africa before they choose to travel abroad to achieve their dreams in life. They already know what awaits them in Belgium before they leave Nigeria but they choose to travel to Belgium because they are marginalized. Therefore, in order to have lives of their own, not the life controlled by the men in their lives characterized by sex abuse, lack of parental care and evil effects of war, they choose going into prostitution rather than dying in hardship when they are told that they can make huge sum of money in Europe and be empowered within a short space of time.

Literary realism and feminist approaches to literary criticism are used in this study. Literary realist authors depict everyday activities and experiences as they are. Campbell in her Realism in American Literature (2012) points out that literary criticism is the faithful representation of reality or verisimilitude (p. 482). Chase in The American Novel and its Tradition (1957) posits that in realism, characters appear in their real complexity of temperament and motive in their relation to nature, to each other and to their social class. He further stresses that class is important in realism (p. 12). In this study, the authors of Trafficked and On Black Sisters' Street present forms of corruption going on in Nigeria/Africa in these novels. The traffickers are the upper-class citizens while these young girls that are lured into this kind of modern slavery are the lower-class citizens. The everyday activities and experiences of these trafficked girls presented in the novels act as a satire, criticizing the ills in the society with the hope of effecting a change.

Feminist criticism is a distinctive approach to literature inaugurated in the late 1960 's which has reached out in so many directions. It is a movement that disapproves of the limitations imposed on women and promotes equality of the 
male and female genders in all aspects of life. It is devoted to criticizing works of male authors and takes interest in female creative processes. But Pratt points out in The New Female Criticism (1975) that it would be better to turn one's attention from attack to defense, from examples of distorted images of women to examples of healthier representation (p. 877). Stevens and Stewart in their A Critical Guide to Literary Criticism and Research (1987) posit that some female critics have used criticism to call for change in the society (p. 77) and Heilbrun, in support of this, stresses that Reinventing Womanhood (1979) makes literary criticism a part of her effort to promote the struggle for female selfhood (p. 202).

With regard to this study, Adimora-Ezeigbo and Unigwe present the trauma suffered these young girls lured into trafficking as they are turned into sex slaves and prostitutes to make money for the traffickers. They also represent child abuse, lack of parental care, peer pressure, official strikes that suspend the functions of so many governmental establishments like universities and secondary schools in Nigeria as the pressing factors that lead to girl trafficking. These make young girls accept offers from international bodies without verifying whether they are real or fake. By this the authors highlight poor education and unemployment as the reasons for much girl trafficking in African countries. They also portray the male characters in the novel trying to take advantage of the young trafficked girls' sorry situation. This is seen through the actions of the journalists who aim to expose the personalities of the trafficked girls to boost their professions. The security man at the rehabilitation centre also tries to rape Nneoma - one of the trafficked girls in Trafficked - whom he is supposed to protect. It is also portrayed in the actions of Dele in On Black Sisters' Street who only agrees to forgive Ama, one of the victims of trafficking for at first turning down his proposal to take her to Europe by having sex with her before she leaves for Belgium. 'II forgive you I swear! ...' He pulled Ama close and she could feel his penis harden through his trousers. 'I shall sample you before you go'. He laughed," (p. 167-168). The actions of the male characters add to the trauma of the girls. The oneness of spirit of the trafficked girls that is juxtaposed with the trauma of the girls and the vulnerability of young girls in the hands of greedy and immoral lecturers as presented by Ezeigbo vividly bring out the victimization and marginalization of women. The emphasis of Ezeigbo and Unigwe as female writers on the marginalization of women, is to call on all women to preserve their womanhood and stand out and fight against all practices in the society that are against women and girls.

In On Black Sisters' Street, Ama, one of the trafficked girls tells the stories of her journey to Belgium and says: "I made this choice; at least, I was given a choice. I came here with my eyes wide open ... I get food, I have a roof over my head, I have a life" (p. 114). 
Other social occurrences presented in Trafficked which push young girls into the quest for greener pasture outside Africa are frequent official strikes which keep young girls out of school for a long time, unemployment and acts of corruption like lecturers extorting money from students, and male lecturers victimizing female students if they refuse to sleep with them. The trafficked victims are taken to shrines where they are forced to take oaths before their departure to Europe. The trafficked girls are given concoctions and the traffickers use rituals to threaten them if they try to escape without paying all the money the traffickers demand from them. The girls are told that if they disobey their owners, they would run mad or the oath would cause their death. This helps the victims to have courage even in their misery and prevents them from running away or giving evidence for the arrest and prosecution of the traffickers. The traffickers bribe the police in Europe with huge amounts of money to silence any of their victims that try to escape or has the courage to bring them to justice. This is why in On Black Sisters' Street, Efe, Ama and Joyce have no option than to accept the traumatic ordeal they are passing through even after Sisi, one of them dies and Madam and Segun (those in the trafficking network) show no concern. The girls find solace in telling their tales of woe. Their stories are not in vain because their common struggle for survival becomes a bond of love in their lives. The tales make them accept one another as sisters. This unity and oneness of their spirit invigorate their inner beings which are their true selves and the redressed content of the unconscious are awoken. Ama breaks down in tears and calls for an embrace from the other two: 'She is crying, 'Come here,' she says to Joyce and Efe. She stands up and spreads her arms. Joyce gets up and is enclosed in Ama's embrace. Efe stands up too and puts one arm around each woman. Their tears mingle and the only sound in the room is that of weeping" (p. 290).

They know that they are in the struggle for their freedom together and also that unity is strength. The fight for freedom will be achieved when they face their fear and fight the cause together. One may ask, what is this their fear? Their fear has been that "Madam has the police in her pocket" (p. 290) but they agree never to allow Madam and Dele to go unpunished. Ama, as the spokesman of the trafficked girls, takes decisions for the three while the other two concur: "We're not happy here. None of us is. We work hard to make somebody else rich. Madam treats us like animals. Why are we doing this? And I don't believe that we cannot find an honest policeman. I don't believe that for a second! We report Madam and who knows, maybe we can even get asylum here. There are always people looking for causes to support. They can support us. We can be free. Madam has no right to our bodies, and neither does Dele. I don't want to think one day I will be dead here and all Madam will do is complain about how bad my death is for business. I don't know 
what will happen to us, but I want to make sure Madam and Dele get punished,“ (p. 290).

Nadaswaran (2014) in her 'Transcendence' calls these assertive female characters, characters who are no longer at the periphery, but female characters that the feminist authors place in central depictions to articulate as well as assert their individual selves (p. 171). In Trafficked, Nneoma and Efe are also such assertive female characters. The author's presentation of these kinds of female characters is to foster other women's assertion. Trafficked explores how nongovernmental organizations, parastatals and humanitarian societies can fight this form of disguised modern slavery by offering good counselling and rehabilitation to the victims. Oasis, the rehabilitation centre in the novel is owned by women and Akachi Ezeigbo uses this to urge all women both old and young to stand out and contribute to the fight against trafficking in order to preserve the dignity of the female child. That Trafficked ends well as the protagonist gets admitted into the university to get her degree is not a guarantee that all such victims may escape the danger inherent in the trade. True, the protagonist, Nneoma, is reconnected to her fiancé from whom she is running away, and Efe, her friend, gets married to a man that loves her and lives happily after. However, what happened to the other deported victims at Oasis is not mentioned. Chika Unigwe's On Black Sisters' Street has a tragic end. One of the four trafficked girls is mysteriously killed and this is an eye-opener to young girls who have illusory dreams of becoming millionaires and aspire to travel out of the country with little or no qualification and no legal documents. It makes young girls to re-think and strive to survive in their home countries than travel to Europe to face the hazards which accompany the trade.

The interpretations of the activities in the novels and experiences of trafficked girls in this research work not only describe human trafficking as a crime against humanity and a violation of human rights but also the need for the society to fight against this kind of modern slavery. Moreover, the bringing to the limelight the significance of rehabilitation to the trafficked girls and the need for women assertion make these theories (realistic criticism and feminist theory) very relevant to this study.

\section{Social occurrences as the pressing factors that enhance girl trafficking}

The pursuit of wealth and power has turned some people into performing actions that rate them as wild animals that feed on human flesh. Most Africans thirst for power and wealth to the detriment of the innocent masses. These government officials see the seat of government as a great opportunity to enrich themselves so that even in their fourth generation, their great-grand children would not lack. They send their children abroad to acquire good education while turning deaf ears to the cry of the masses to improve education in their countries. 
For this reason, the educationalists/educators have embarked on a lot of strikes to draw the attention of the government but to no avail. Most times, the strike actions linger for up to six months or even a whole academic year. The young students in secondary schools and tertiary institutions being out of the classrooms for such a long period creates more problems for the society and young girls are mostly victims of the circumstance. Some of them are forced into marriage by their parents, some go into hawking goods which exposes them to sexual abuse, while some seek 'greener pasture' in the hands of deceptive traffickers that fill the nooks and crannies of some African countries.

\section{The trafficked girls' life experiences in Nigeria before relocating to Europe}

In agreement with an adage which says that an idle mind is the devil's workshop, the long strike actions contribute to the young people's greater engagement in some irrelevant social gatherings that bring them together. They have much time to listen to sweet stories formulated by the traffickers which they use to convince their victims of their legitimacy. Their togetherness when they are not engaged in academic works to keep them busy enhances peer pressure which is another factor that promotes trafficking.

This is portrayed in Trafficked through Nneoma and Efe's tales of their misery which reveals how the two girls were lured into this international sex trade. Nneoma gets the information from a friend and a classmate that some people had helped her secure a teaching appointment in the United Kingdom. Nneoma being a trained teacher, a National Education Certificate holder shows interest. She travels all the way from the East to Lagos, Nigeria without telling anybody, including her parents, to be introduced to the people she sees as the 'messiahs'. "In no time, Nneoma and five other young women get their passports and flight tickets and are given appointment letters signed by people with English names and also shown pictures of the schools they would be going to teach" (p. 127). Efe was also lured into the trade when she read an advertisement in a newspaper when she went to visit her cousin in Lagos which asked young girls and women who wished to work abroad to come to a certain address to be interviewed. She responded to the advertisement without letting her cousin know because Efe, who comes from a poor family that "struggles to put meals on the table", sees it as a golden opportunity to "leave the country" (p. 98-99). It is therefore the quest for economic freedom that gets the two young girls ensnared into this international sex trade. They want to get jobs where they will be paid in the currency that would provide a better life for them and their families.

Through the narration from the three trafficked women while they exchange memories of their moments with Sisi in Chika Unigwe's On Black Sisters' Street, the 
women ponder on the circumstances surrounding the death of Sisi, one of them. The shared memories transform to intimate disclosures of the torture they face in the hands of their exploiters. They go on to share their life histories, hiding their true names and family members from one another which might be because of the shame associated with sex trade. In a bid to try to escape the prostitution, Sisi turns up dead and the women wonder why Madam and Segun go about their business as usual, as if Sisi is not dead. The police investigation comes up with racism as motive for the murder of Sisi just as usual with such deaths but the women keep wondering why Madam keeps burning incense to rid the flat of Sisi's spirit. Not only that, they also keep wondering why Segun would take Sisi out in his car; why nothing is known about Segun's job in the city of Antwerp except that he fixes things in the house and acts as Madam's driver. "While they cannot ... determine the exact nature of his job, one thing about him is not in doubt: when there's a job to be done in the house - lights that need changing, a cupboard handle that needs fixing, nails to be hammered into the wall for Madam's paintings, a table to be made - he is the man for it," (p. 107).

Their tales of their lives is a mode of expression used by the authors to bring to the limelight the common fate of the trafficked victims as well as the realities of life they face in the sex trade. From the tales, it is revealed that Sisi (Chisom) is a graduate from the University of Lagos who is lured into the trade because she could not find a job in Nigeria. She comes from a very poor family and her parents encourage her to embark on the journey because they are hoping that she would raise their status in the society.

Ama is continually raped by her mother's husband whom she thought is her father from her eighth birth day night until when she starts menstruating at eleven years. Her stepfather, Brother Cyril, is an assistant pastor at the Church of the Twelve Apostles of the Almighty Yahweh, Jehovah El Shaddai, Jehovah Jireh, one of the biggest churches in the city of Enugu and is known as a very devoted Christian. He always wears white clothes as a symbol of his purity - "White for Holiness" ( 131). Ama would cry her eyes out all night but her mother whom she says walks around in a deliberate state of blindness because she could not see into her heart, would look at her in the morning and take it that she had 'apollo' because her eyes were red. The presentation of the character, Ama's mother in the novel is to highlight the nonchalant attitude of some mothers in child upbringing. A good mother should have tried to find out the cause of the frequent 'apollo' infection on her daughter but Ama's mother does give her daughter proper health care.

Ama was enduring her misery, dying in silence, but the last straw that broke the camel's back was when her stepfather shouted at her for failing JAMB exams for two years, calling her lazybones - "Get out of my face, you lazybones ... Idiot ... how do you expect to pass JAMB? You think passing JAMB is drinking akamu? Get 
out of my sight..." (p. 147). The anger boiling up in Ama was so much that she had to discard her normal way of silence and display courage to confront him. She knows that she must talk if she wants to be liberated. Her tongue loosens and she shouts back at him, "You call yourself my father? You call yourself a pastor? You disgust me! I na-aso m oyi!" (p. 147). Unigwe as a feminist presents Ama's development from her oppressed infancy to maturity where she regains her voice. She stands out to challenge the man who has the intension of keeping her in perpetual suffering.

Ama ignores her mother's attempt to make her regret her actions. She tells Ama to shut up but she lets loose her anger and let her mother know how she has been sexually violated and abused by a man that calls himself her father. The bold step she choose opens a new chapter of her life. The truth about her life is revealed. Brother Cyril's hypocrisy is revealed more and more. His 'holiness' and his wife's 'chastity' before their marriage that he announces to the congregation of his church any time he testifies to make the church see Rose, his wife as a model is to be questioned. Rose, the chastity personified according to her husband was impregnated out of wedlock and he married her to cover up her sins. And also in order for the two hypocrites to cover up their sins, they have no option than to chase Ama out of the house so that the world will not make mockery of them. This scenario brings Ama to know her true self. Being deprived of the cares of her parents, Ama keeps struggling to survive and falls into the hands of Dele, the pimp that introduces her to the sex trade.

Efe is a teenage single mother who is tricked into living immoral life by Titus, a man that has impregnated many other young girls. Efe is struggling to raise her son, Lucky Ikponwosa, fondly called LI, without help from the child's father. Titus promises her heaven and earth to lure her into having sexual relationship with him only to abandon her in a hotel room the night she tells him she is pregnant. "Then he got up, turned his broad back to her, picked up his car keys from the table beside and walked out of the hotel room, closing the door so gently behind him that it made no noise" (p. 59). The presentation of Titus abandoning Efe in the novel highlights the trauma some women go through in the hands of some men in African society. Such men always look for flimsy excuses to shift their responsibilities to women.

In the same way, Efe's father leaves his responsibilities as a father to Efe after the death of Efe's mother. He turns into a drunk and is unable to carry out his responsibility of feeding his children. It is Efe's taking over the responsibility of caring for her other siblings that gets her lured to Titus. Titus has enough money to ensure that Efe and her son live in comfort but refuses to own up to his responsibility. Efe's father holds on to the death of his wife for his irresponsible life. Unigwe uses the actions of Titus and Efe's father (his Post Traumatic Stress 
Disorder) to inform usthat women take over when men fail. To add to what Efe's father and Titus have done to her, Dele seizes the opportunity of her vulnerable situation to get her introduced to the sex trade. Dele represents some men who are purveyors of our society but instead of helping the poor, especially women, they always derive pleasure in seeing women exploited. "She had agreed to his terms before she asked what she was expected to do abroad. 'Clean?' To which Dele had laughed and said, 'No, Sales.' And it was the way he sized her up, his eyes going from her face to her breasts to her calves under her knee-length skirt, that told her what sort of sales she was going to be involved in" (p. 82).

Joyce (Alek) is not even a Nigerian and she has to reveal her identity to the girls. The mention of her real name, Alek, to the housemates gives her life fulfilment 'Alek: it sounds like a homecoming, like the origin of life' (p. 180). She is a Sudanese who is devastated in life due to the evil effect of war. She is raped and left naked by a group of soldiers who had earlier killed the other members of her family. She moves to the refugee camp with other women and children that survive the attack on their families where she lives her hopeless life. Polycarp, a Nigerian soldier, on relief duty in Sudan meets her, falls in love with her and restores her hopeless life. He brings her back to Nigeria to marry her but his family refuses to accept her because of cultural barrier. Polycarp and Dele arrange for Joyce's relocation to Belgium and she has no option than to accept her fate without having any knowledge of what awaits her abroad.

In Trafficked, Nneoma and Efe, in the course of narrating their ordeal, find out that their stories are similar. While they are thinking of the money they would make in the United Kingdom, the traffickers exhibit what induced worry in the girls. They suspect that they might not be paying back only the money the traffickers paid to procure their passports and flight tickets. The exploiters take their victims to shrines where they swear oaths and sometimes eat concoctions and they are told what the consequences would be if they disregard the terms of the agreement, disobey them or cut off without settling their debts. Nneoma demonstrates her surprise when Efe talks about the oath taking thus: "Efe stopped her with a question: 'Where was the oath taken? In a Shrine?' 'No, they used the Bible and an image of an arusi.' 'In my case, they took us to a shrine somewhere between Lagos and Ibadan'” (p. 128).

All these make the situations of almost all the trafficked young girls deplorable. To add to their ordeal, they live traumatic life in Europe because instead of the better life they hope for, they face greater torture in the hands of the exploiters. Adimora-Ezeigbo (2008) and Unigwe's use of the first person narrative technique in the trafficked girls' narration of the life experiences is to disclose the depth of the deception of the traffickers. It is also to make them tell their tales as a form of 
speaking out and calling for both the individual and collective fight against the societal ill.

\section{The trafficked girls' day-to day experiences in Europe}

The narrative of the trafficked girls becomes more heartrending as they tell their day to day experiences in the hands of their exploiters. In Trafficked, Nneoma in narrating her story to Efe says: "In Italy I discover I am trafficked. I have no say in the matter. There's a woman called Madam Dollar - nothing comes between her and money. She owns us and the man, whom we learn to call Captain, is her bodyguard" (p. 128).

These traffickers keep the girls as prisoners in Europe after collecting their passports. They claim they have spent a lot of money getting these passports and tickets therefore, these girls are told that they will only regain their freedom if they pay all the money the traffickers spent on them. The traffickers sell off the girls to other traffickers in their network if they feel that they have got enough money from the girls instead of freeing them. The girls are completely devastated by the life they are forced to live, "hit the night street, waiting for customers, winter, spring, summer and autumn; come back at dawn, wash, eat and sleep till all begins again at night" (p. 129).

For instance, Madam Dollar makes Nneoma walk the streets of Rome looking for sex customers for three years and still she claims she has not made enough money to pay her back all she has spent on her. When she is tired of Nneoma, she sells her off to another trafficker in London who has to drive her only at night from Rome to London so that she would not trace the way. This brings out clearly the networking nature of trafficking. Baron buys Nneoma and two other girls from Madam Dollar and Nneoma is happy because she thinks that Baron has come to rescue her. She later realizes that she has jumped from the frying pot into the fire instead. Baron sends out the other girls to brothels and keeps Nneoma in his flat. He locks her up, brings in men for her in his flat, rapes her and beats her up any time she refuses to have oral sex or the sex position he wants. Locking Nneoma up portrays that the pimps want to keep the trafficked girls in perpetual slavery to be making money for them.

Efe also narrates her own experience trying to highlight the perpetual enslavement the trafficked girls suffer, in Europe: "It was terrible. I was sold to a woman called Madam Gold, a Nigerian. She was vicious. She used us shamelessly, made us walk the streets every night. ... Madam Gold sold me to a pimp - a white man - after four years of slaving for her. I worked for my 'new owner' for two years before I escaped" (p. 99-100). 
Nneoma also narrates the shame they feel for being ridiculed in the street by people. The irony in the teasing is that it is the men that come to the girls for sex that call them prostitutes. As they are sharing their memories, Nneoma asserts that "Sometimes while we are standing in the red light area where other prostitutes line up, youths come shouting 'Puta! Puta! At such moments, I am completely overwhelmed by shame" (p. 130).

Efe confirms it by adding her own experience, "Yes I felt that way too, ... They called us whores, yet they came to us" (p.130). Upon all the humiliation and shame, the brutality of Captain, Madam Dollar's bodyguard, on Nneoma for not bringing back the amount of money Madam Dollar expects from her from the sex trade, standing in the red light every night still awaits her and she laments over the agonizing experience: 'I'm often assaulted by Captain because I'm stubborn and bring the least amount of money home' (p. 129).

Chika Unigwe is also able to evoke a terrifying, brutal and alarming world of the trafficked girls in On Black Sisters' Street. The girls, Ama, Efe, Sisi and Joyce, stand at windows of Antwerp's red-light district selling their bodies to men in order to make enough money. They live like slaves to Madam in Belgium and Dele in Nigeria. Just like the trafficked victims in Trafficked, they narrate their own horrible day-to-day experiences. The most painful of them all is their very first prostitution experiences which serve as the initiation into the shameful trade. In expressing the pain and agony Sisi passes through, Unigwe points out that "she baptised herself into the profession with tears, hot and livid, down her checks, salty in her mouth, feeling intense pain ..." (p. 213).

The girls curse the day they met Dele and regret why they were taken in by his promise of wealth and glamour, especially when the men that sleep with them call them whores. For instance, when a customer asked Sisi to "lie spreadeagled, while he yelled whore at her and jerked off to that, she felt something akin to revulsion" (p. 248). They are immensely wounded in the spirit as they realise that the promises of wealth and glamour they are given in Nigeria are just a mirage, "She began to wish she had never left home, rueing the day she'd met Dele" (p. 248).

Sisi, Efe, Ama and Joyce live like slaves, condemned to eternal servitude. After all the pains from the disgusting trade, a greater portion of the money goes to Dele and Madam. They have been living in the same house but it is the death of Sisi that bonds them together. They console themselves with the tales of their past and present, revealing to the readers more of the pains, fear and agony of women who go to the red-light district for prostitution.

The feeling of happiness that the trafficked girls had after listening to their stories is what Adimora-Ezeigbo and Unigwe use to make the readers understand that emotional release leads to empowerment. Revealing the circumstances that led to their being trafficked and the torture they faced in Europe make them feel 
free from the guilt of dying in silence. In Trafficked, Adimora-Ezeigbo highlights that Nneoma and Efe burst out laughing after listening to their stories because they serve as a balm for their wounded hearts. Their joyful hearts radiate on their faces and they are excited to know that they are still as beautiful as ever. "Efe exclaimed, gazing at Nneoma. 'Look at those dimples! I didn't know you had dimples. Do you know that this is the first time you laughed since I met you?' Her voice bubbled with excitement" (p. 136).

They are relieved of their fear. Nneoma confesses her feeling of joy in seeing somebody that listens to her story. It is not just anybody but someone that understands the misery of the trade and she says, "I feel cleansed. My body feels light. Efe thank you for listening to my story" (p. 135). The love that binds them together becomes deeper and they demonstrate their restoration: "Nneoma threw her head back and gurgled with laughter. She laughed so hard that tears ran down her face. Efe also laughed, sure that Nneoma's tears were not caused by sorrow this time, (p. 136). Ama, Efe and Joyce in On Black Sisters' Street in the same way demonstrate their sisterhood after listening to their stories. 'Now we are sisters ... and would be friends for ever" (p. 290).

\section{The fight against human trafficking and the way forward}

A common attribute of Akachi Adimora-Ezeigbo and Chika Unigwe from these novels is that they are writers with vision. The trafficked girls pour out the contents of their heart to bring to the limelight their misery due to the traffickers preying on them. The interest of the traffickers is to enrich their pockets by using the lives of their fellow human beings, thereby making themselves not different from ritual murderers that use the life and body parts of their fellow men for money rituals. The authors are revolutionaries and they call for change in the behavioural attitude of people. They use the novels to speak against some members of the African society watching innocent young girls enrich other people's pockets to the detriment of their own lives and going about their businesses as if the traffickers cannot be brought to book. Adimora-Ezeigbo and Unigwe's revolutionary vision is a perception of life that aims at changing lives through the art medium and it is demonstrated in these novels. Aderemi Bamikunle in his 'The Revolutionary Vision of Olu Obafemi's Theatre' (2000) asserts that there are two forms of vision - Reactionary and Revolutionary. He further opines that reactionary vision is the view of despair as natural and unchangeable while revolutionary vision is the vision that accepts every human situation as changeable and sets about changing it (p. 103). There is an increase in human trafficking especially in Africa in the $21^{\text {st }}$ century because most people in Africa have the reactionary vision. It is a serious epidemic that needs to be eradicated. Its adverse effects on our youths are numerous, especially on the young 
girls, our future mothers. In Trafficked, Adimora-Ezeigbo presents Oasis, a non governmental Skill Acquisition and Rehabilitation Centre, which specializes in reorientating the deported trafficked girls who have been physically, sexually and psychologically abused. The representation of Oasis is to organise the girls so that they would be established again. They are trained in skills and the training helps them to pick up the pieces of their lives and have a livelihood. Therefore the representation of Oasis is to advocate for skill acquisition programmes for youth empowerment in Africa. Our youths are our future leaders and if they are empowered, they would make Africa a better place.

Adimora- Ezeigbo's creation of female characters like Dr. Okehi and the group of women that are owners of Oasis in Trafficked, is to place women in the forefront of the fight against human trafficking. The young victims are used for different sexual activities both with human beings and animals and in very dehumanizing positions. They are infected with various sexually transited diseases and some are even killed and thrown into the streets. Some who are lucky to be deported back to Africa are obsessed with fear and continue to have sleepless nights because of terrible nightmares. Women are most vulnerable to the traffickers; therefore, though everybody is to fight human trafficking, the fight should be led by women. It may not be so easy to stamp out girl trafficking, but proper counselling with skill acquisition makes young girls self-employed. It is easier for an empowered woman to be creative, dig deeper to discover her potentialities and discard the traffickers' 'attractive' offers. If some of the young trafficked girls, especially the graduates had had the opportunity to be trained in skills, they would have stayed back in their countries to start-up better and respectful means of livelihood.

Adimora-Ezeigbo and Unigwe in the novels also employ the technique of storytelling. The trafficked girls discard the attitude of silence and voice their feelings. The girls' stories captivate the readers and ginger them, especially all women to awake, rise and join in the struggle for freedom and survival of women in Africa. Adimora-Ezeigbo and Unigwe as female authors create the trafficked girls that tell the stories of their lives to advocate the sharing of life experiences by women. Through the tales of the four trafficked girls in On Black Sisters' Street, we realise that they not only share a house in Zwartezusterstraat but they also propose to go into women bonding for greater achievements. For instance, Ama will open a boutique that would be managed by her aunt, Mama Eko while Joyce will set up a school at Yaba that would be called Sisi International Primary and Secondary School. The teachers to be employed in the school would be mainly young women. Efe says she wants to be a writer. "It was my biggest dream. I was going to write books and become famous. She laughs" (p. 241). The female authors present the dreams of the trafficked girls that women must go to school, women must talk (tell their stories) and if possible write themselves into being. They want 
all women to know that the era of a woman saying that 'I am just a woman' has gone, rather the woman must stand against all traditions and norms that want to keep her in perpetual slavery.

\section{Conclusion}

Akachi Adimora-Ezeigbo's Trafficked and Chika Unigwe's On Black Sisters' Street expose the entrapment of young trafficked girls to the trade, the ugly brutal and terrifying day-to-day experiences of the victims and the immanent nature of their misery. These authors devise a more powerful way of revealing the depth of the victims' depression through the victims telling their captivating stories. The narrative technique of the narration employed by the authors is aimed at not only explaining the detailed experiences of the trafficked victims but also to portray the authors' vision to change the social, political, educational and economic systems in African nations that have left the masses as 'a fly in a spider's web'. Seeing that women are more vulnerable to the traffickers, the female authors take the bull by the horn through their revolutionary spirit to urge everyone in the African society to fight and track down the traffickers through their networks. They also devise practical means of remedying the damage on the young victims by calling on public-spirited individuals, Non-Governmental Organizations as well as Governments in Africa to build rehabilitation centres for them. Proper counselling, skill mentoring and acquisition will help to remould the lives of the young trafficked girls and also add to their positive impact in the society. The authors appeal to the society through their literary works for the fight against human trafficking and rehabilitation of the trafficked victims is because literature is a suitable vehicle for the purpose of achieving the change they envisaged.

\section{References}

Adimora-Ezeigbo, A. (2008). Trafficked. Lagos: Lantern Publishers (Nig) Limited. Bamikunle, A. (2000). The Revolutionary Vision of Olu Obafemi's Theatre. In Oni, D. \& Ododo, S. E. (Eds.), Larger Than His Frame: Critical Studies and Reflections on Olu Obafemi (103-114). Lagos: CBAAC.

Campbell, M. D. (2012). Realism in American Literature 1860-1890. Literary Movements, 10, May 2012.

Chase, R. (1957). The American Novel and its Tradition. New York: Doubleday \& company Inc.

Heibrun, C. G. (1979). Reinventing Womanhood. New York: Norton.

Nadaswaran, S. (2014). Transcendence in Akachi Ezeigbo's Trafficked. In Adedun, E. A. \& Nweke, B. N. (Eds.), New Perspective on Literary Enigma: A Festschrift in Honour Of Professor Theodora Akachi Adimora-Ezeigbo (pp. 164-172). Ibadan: University Press Ibadan. 
Pratt, A. V. (1975). The New Female Criticism. In Roberts, J. I. (Ed.), Beyond Intellectual Sexism: A New Woman, a New Reality (pp. 175-195). New York: David McKay.

Stevens, B. K. \& Stewart, L. L. (1987). A Guide to Literary Criticism and Research. New York: Holt, Rinehart and Winston.

Unigwe, C. (2009). On Black Sisters Street. London: Jonathan Cape.

UNODC - United Nations Office on Drugs and Crime. (2011). Human Trafficking and Migrant Smuggling. Retrieved from: https://unodc.org/unodc/en/human trafficking/what-is-human-trafficking.htm

UNODC - United Nations Office on Drugs and Crime. (2012). The Protocol to Prevent Suppress and Punish Trafficking in Persons. Retrieved from: https://unodc.org/unodc/en/humantrafficking/what-is-humantrafficking.htm

\section{Contact}

Evelyn Nwachukwu Urama

Department of Languages/Linguistics/Literary Studies/Theatre and Media Arts Federal University Ndufu-Alike Ikwo

Ebonyi State

Nigeria

evelynurama@gmail.com 